truly wild and at large. I recollect to have once found a very small weak plant of it upon the celebrated "Bowder Stone" in Borrowdale, which at the time I thought a treasure; but I was soon afterwards informed, that some person in the neighbourhood had been ornamenting this interesting rock by planting garden-flowers upon it, of which, no doubt, this crumb of "London Pride" was a remnant. Mr. Russell, I see in your Number for Dec. (p. 314), states that he had received the plant some years ago from Clovelly, and that he has this year "verified the locality himself," and "is much inclined to admit the station as a true one." Of the correctness of this statement I do not mean to venture an opinion, not having visited the place myself. But with this exception, if it prove to be one, I am much disposed to coincide with Mr. Baines's reviewer (p. 216), that the plant in question "is hardly found in England, except in Yorkshire." I have visited the wild sequestered station, "Hessleton Gill," in that county, and have there found S. umbrosa growing luxuriantly and apparently wild, though occupying a space of no very great extent, and am not surprised at any botanist asserting that here, at any rate, the plant is truly native. I could, however, assign reasons, which yet it would be tedious to detail at length, for suspecting, if not for believing, that even here, in this retired spot, the plant is not truly indigenous, but introduced by the hand of man; and, in short, that S. umbrosa, the "London Pride" of our gardens, is not of native but exotic origin, though it has been, in a manner, naturalized in various parts of our island.

I am, Sir, yours faithfully, W. T. BREE.

Allesley Rectory, near Coventry, Dec. 22, 1840.

\title{
XLVI.-On some new or rare Fish occurring on the Coast of
} Ireland. By Frederick M'Coy, Esq., M.G.S., \&c.

The following notices of new or rare fish found on the coast of Ireland, have been drawn up from specimens contained, for the most part, in the Museum of the Royal Dublin Society, and which have been, with few exceptions, taken during the last winter by Mr. William MacCalla, a very intelligent and successful collector of marine productions. Besides the subjects of the present communication, he has enriched the Society's collection with many rare and interesting species of Crustacea and naked Mollusca from different parts of the coast, which may, perhaps, form the subject of a 
future paper. To my friend Dr. Scouler, Geological Professor to the Dublin Society, I am indebted for many valuable notes on the habits, \&c., of the various species now treated of, as well as for his kindness and polite attention whenever I wished to examine any of the specimens under his care.

Trigla Blochii. This is a rare fish with us, but several specimens have been brought to me from Kingstown, Dublin.

Cottus Groenlandicus (Richardson's Fauna, Br. Ann. p. 297, pl. 95, fig. 2). A fine specimen of this fish, nearly 10 inches long, is in the collection of the Royal Dublin Society, from Kingstown, near Dublin; two other specimens were taken during the last week in the bay, and are now in my possession; and last evening I procured a beautiful specimen near the mouth of the river Liffey, which is also in my collection. I believe this fish is new to the European Fauna.

Thynnus Pelamys, Bonito. A splendid specimen of this rare fish, taken off the coast of Dublin, is now in the collection of the Royal Dublin Society.

Mugil Chelo and Mugil Capito have occurred to me in nearly equal abundance at some periods of the year in Dublin bay. These species are very nearly allied. Specimens of both are in the Museum of the Royal Dublin Society.

\section{Gobius fuliginosus (M'Coy).}

Length 2 inches, depth 4 lines. Dorsals continuous : rays very long, second and third longest; first ray half a line shorter than the second; third ray $3 \frac{\mathrm{I}}{2}$ lines in length in the second dorsal ; third and fourth rather the longest in the first dorsal; pectoral, when laid flat against the side, reaches to opposite the third ray of the second dorsal; from the anterior base of the ventral fins to the vent, 6 lines; from the same point to the apex of the ventral fin, $3 \frac{1}{2}$ lines : eyes moderate, half their diameter apart. Lower jaw longest; the gape, when the mouth is shut, extending obliquely upwards from the external angle : forehead and nape convex, no sulcus; beneath white, sides and back dusky; a few obscure spots on the lateral line: ventral fin white, the rest dusky with blackish margins; snout and space between the eyes blackish, and a few blackish spots on the chin (in spirits).

$$
\text { D. } 6.16 \text {; C. } 17 \text {; A. } 13 \text {; P. } 20 \text {; V. } 9 \text {. }
$$

The posterior rays of the anal fin longest, last somewhat shorter.

The only specimen I have seen was from Connamara, taken in company with G. niger.

Gobius reticulatus. Two specimens of this most beautiful Goby were taken by dredging in shallow water in Dublin bay. 
The beautiful rosy tint of the dorsal fins first attracted my attention. This fish has not, I believe, been discovered in the British seas before; I have only seen these two specimens, one of which is in the Museum of the Royal Dublin Society, and the other in my own collection. The species is known to ichthyologists only by the descriptions of Cuvier and Valenciennes, who had an opportunity of seeing but one specimen brought by M. Bibron from Sicily, and preserved in spirits, when it had lost some of its characteristics, particularly the pink colour of the dorsal fins ; a description, therefore, from living specimens may not be unacceptable, particularly to the British naturalist, to whose Fauna it is now added.

Length 2 inches and 1 line; depth at base of first dorsal 4 lines : head depressed; snout very short, tumid, convex; lower jaw longer than the upper: eyes very large, approximate ; a sulcus or groove runs from between the eyes to the base of the first dorsal; cheeks tumid ; eyes within a third of their diameter apart; from the anterior edge of the orbit to the tip of the upper jaw, less than the diameter of the eye; first dorsal with the second ray longest, the others gradually decreasing.

$$
\text { D. } 6.10 \text {; P. } 19 \text {; A. } 10 \text {; C. } 15 \text {; V. } 10 .
$$

The head is one-fourth the entire length; the depth at the base of the pectorals one-sixth the entire length; width at base of the pectorals one-sixth the entire length, caudal fin included; the ventral fin reaches as far as the posterior margin of the vent; the pectorals scarcely further. Colour (in spirits), body pale fuilvous yellow, reticulated with black lines, something paler below: fins white, the anal and ventral in the adult fish being slightly margined with dusky; the pectoral, ventral, anal and caudal fins without spots; the two dorsals, when the fish was alive, were of a very beautiful rose colour; these two fins are thickly marked with large black spots, placed, for the most part, between the rays. On the anterior dorsal there is a series of six very large black spots extending from the posterior angle to about the middle of the anterior ray; this row is consequently midway between the body and the margin of the fins; beneath these there is another series of four smaller black spots communicating at the anterior ray, and between the longest set and the margin of the fin there are a few straggling black spots inferior in size to those of the first series; beneath these there is, anteriorly, a set of five or six smaller black spots; above each of the spots in the principal row is a small black dot. The second dorsal has nearly the same arrangement of the spots, but has them in greater number.

Crenilabrus Cornubicus. Rare in Dublin bay.

Merlangus virens. Rare in Dublin bay.

Motella tricirrata. Very common in Roundstone bay, Connemara. 
Platessa microcephala. Scarce in Dublin bay.

Rhombus megastomus. Kingstown; not uncommon.

Monochirus minutus. Little Sole. And also the variegated Sole occur in tolerable abundance, right off Dublin bay, between the light-ship and the harbour.

Ammodytes Tobianus. This fish is frequent in the sand at Malahide, county Dublin, in company with the common species.

Acus anguineus. This elegant species is common in certain localities in Connemara.

Raia radiata. Starry Ray. A small specimen of this Ray, five inches in breadth, taken with the species mentioned below, in Dublin bay, is remarkable for having the body almost destitute of spines; those, however, which are found on the snout and anterior margin of the pectorals, preserve the peculiar character of the species. This want of spines on the body is the more remarkable, as Donovan's original specimen was of even smaller size, and was abundantly supplied with spines. In all other respects the specimens are identical.

Raia intermedia. Two specimens of this rare Skate, taken in Dublin bay, agreed perfectly with each other; neither of them were spotted; besides the one large spine before the eye, it had another of equal size behind the orbit, and one small blunt one external, and a little anterior to the one before the eye; upper surface of the body rather brownish, lower purplish grey. Those two specimens it will be found agree perfectly with two fishes obtained by Dr. Parnell at Queensferry, considered by him as a mere variety of his $R$. intermedia. Length 13 inches; it varies slightly in the proportions of length to breadth; the number of spines on the tail also varies, being in one of the specimens before me 15 , in the other 16 , to the base of the anterior dorsal: Dr. Parnell's specimens had 18; the two dorsals separated by a spiny tubercle. In other respects perfectly identical.

Raia? I will now describe a Ray, which I cannot identify with any of those described. It is a small species, seldom exceeding 17 or 18 inches in length, and 9 or 10 in breadth. It possesses the peculiar outline of the Sandy Ray of Couch; it likewise possesses the semicircle of spines on the inner margin of the eye, the spines at the tip of the snout, and the four short rows of spines in the middle of the back, and the teeth precisely as in that species; all the specimens I have seen had one spot on each pectoral fin, as is commonly seen in the Homelyn Ray; that is, a circular spot of chocolate- 
brown surrounded by a circle of white irregular spots, and some irregular white markings in the centre, instead of the numerous small white spots of the Sandy Ray; but as colouring is of no manner of importance in this family, I need only mention that the species of which I now write appears to me to differ from the Sandy Ray in having the surface of the body covered with minute spines directed backwards, and by the length of the tail, which measures, from the vent to the tip of the tail, two-sevenths more than the length of the body measured from the same point to the tip of the snout; the body being smooth in the Sandy Ray, and the tail remarkably short; which, in addition to its rough skin, and its having the characteristic outline and disposition of the spines to be remarked in the Sandy Ray, will distinguish it from the Homelyn. I give a description of a specimen now before me, that the species may be recognized.

Length $16 \frac{1}{2}$ inches.

Descrip. (Form.) Somewhat rhomboidal; the greatest transverse diameter 9 inches; length from the vent to the tip of the snout 7 inches; body moderately thick; snout and anterior part of the pectorals the same as in the Sandy Ray; mouth $1 \frac{1}{2}$ inch; $1 \frac{6}{8}$ inch from the snout; the nostrils in a line with the angles of the mouth; the distance from the angles of the mouth to the nostril one-half of that from the nostril to the margin of the pectoral fin: eyes large ; spiracles rather small, less than the diameter of the orbit, oval, placed obliquely close behind the eye, their longest diameter pointing upwards and outwards; skin above roughened by minute spines directed backwards, largest on the anterior margins of the pectorals; under surface smooth, except beneath the snout and for a little way along the anterior margin of the pectorals; a semicircle of six or eight spines round the inner margin of the orbits, and a few on the tip of the snout; the four short rows of spines about, or rather anterior to the middle of the back, are less distinctly marked in this specimen than in others I have seen. At some distance below these are two rows of equally large hooked spines, which are continued along the tail; there are four rows of large spines on the tail, all directed backwards; but the ridge or central line of the tail might be said to be comparatively unarmed, as in $R$. chagrinia, there being only a few small blunt tubercles in the specimen before me, and even these were absent in a specimen shown me by my friend Captain Portlock; all the larger spines on the body are radiated at their base somewhat as in the Starry Ray, $R$. radiata : tail considerably longer than the body, measuring in the specimen before me 9 inches, equal to the greatest breadth of the fish, rounded above, flattened beneath; dorsals rather closer to each other than the height of the first dorsal fin; pectorals more abruptly rounded off below than in the Sandy Ray. (Colour.) Upper surface of an uniform light yellowish brown, darkest towards the centre; on each 
pectoral one large oval spot of a rich chocolate-brown, surrounded by and containing variously-shaped cream-coloured spots.

Dublin bay.

Raia microcellata. As only three specimens have been recorded of this very rare species, two having occurred to Montagu and one to Mr. Couch, I need scarcely apologize for giving a description of a fine specimen now before me, particularly as it offers one or two trifling variations from those already known.

Drmen. Total length 13 inches; length of tail 7 inches; greatest breadth 9 inches.

Descrip. (Form.) Rhomboidal, the transverse diameter onethird greater than from the snout to the anus; snout short, triangular, projecting half an inch; the anterior margins of the pectorals waved convex; mouth one inch wide; nostrils large, at an equal distance from the corner of the mouth and from the margins of the pectoral fin: eyes small; spiracles moderate; skin above covered with very minute granular spines directed backwards, largest on the snout and anterior margin of the pectorals; beneath entirely smooth, except at the very tip of the snout : mucous orifices remarkably large; before each eye one large broad spine; at the exterior of its base another smaller; behind each eye two or three spines; a row of twenty-five spines commences a little behind the eyes, and continues to the base of the first dorsal; these spines are neither large or much hooked; there is a smaller one between the two dorsals : tail considerably longer than the body, narrow, depressed; the membranous fin-like border to the tail, noticed by Mr. Couch, particularly striking; the two dorsals are more remote than usual, and the rudiment of caudal is larger; the annexed figure shows these fins of the natural size. (Colour.) Upper surface dull brown, with obscure circular whitish spots about the size of a pin; no lines; the sides of the tail elegantly marked with alternate brown and white spots; beneath yellowish white; posterior margin of the pectorals slightly darker.

Dublin bay.

\section{Torpedo emarginata (M'Coy).}

Sp. Char. Head truncated anteriorly, separated from the pectoral fins by a deep notch on each side; spiracles without appendages or processes; anterior dorsal fin entirely behind the ventrals.

Dimen. Total length 2 feet 8 inches; greatest breadth 1 foot 2 inches; thickness 5 inches.

Dhscrip. (Form.) Head distinct, truncated or terminated by a right line anteriorly, emarginate at the sides; breadth in front 7 inches, slightly rounded at the corners : mouth moderate, teeth minute : eyes small, $1 \frac{1}{2}$ inch apart; iris brownish yellow ; behind each a large round or somewhat oval spiracle, without any tooth-like process; brancheal openings five on each side, crescent-shaped; 
skin entirely smooth : about half-way between the spiracles and the posterior terminations of the pectoral fin are situated two large illdefined tubercles, one on each side of the body; two dorsal fins situated very far back on the tail ; anterior dorsal entirely behind the ventrals; height of anterior dorsal 2 inches 5 lines, breadth at base 1 inch 2 lines; length of posterior dorsal 1 inch 3 lines, breadth at base 10 lines; pectoral fins scarcely lobed posteriorly. (Colour.) Uniform blackish brown above, greyish white beneath.

Differs from the $T$. Narke, T. immaculata, $T$. unimaculata, and T. Bancroftii, in being of a uniform brownish black above, not spotted as in those species; from the T. Galvani and $T$. marmorata (Riss.) it will be distinguished by the edges of the spiracles being smooth, and entirely wanting the tooth-like processes with which the spiracles of those species are provided; it is likewise much more slender than any of those species. The specific characters are of course peculiar. The specimen was taken in Dublin bay.

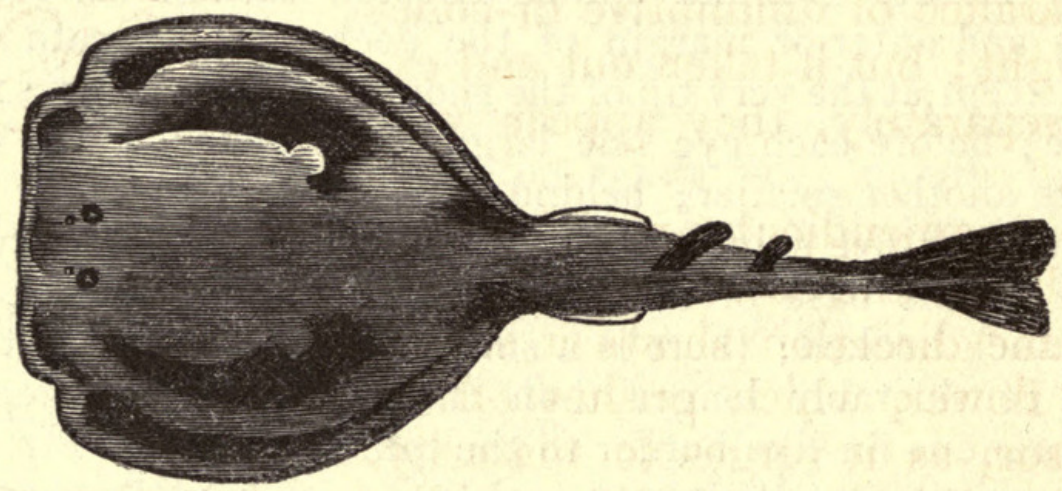

XLVII.-Some further particulars of the Coco de Mer (Lodoicea sechellarum). By George Clarke, Esq.*

THE germ sprouts indifferently, from either side of the cleft between the lobes, turning downwards in shooting, as represented in this section. It suffices for its vegetation that it be placed on the earth; it is not necessary that it be covered, but a shady situation is indispensable. It puts forth only one leaf a year, in general; but there are instances, it is said, in which two are produced; they are, however, exceedingly rare. The leaf at its first appearance is folded together in a most compact manner, so as to resemble a solid piece. This is moreover guarded by a thick downy

* To this gentleman we were indebted for the account given in p. 422 of the Annals. In the 54th volume of the Botanical Magazine, at tab. 2734 , will be found a long and interesting account of this Palm, drawn up by Sir Wm. Hooker, from the communications of Mr. Harrison, who has been long resident at the Seychelles. 


\section{$2 \mathrm{BHL}$ Biodiversity Heritage Library}

McCoy, Frederick. 1841. "XLVI.-On some new or rare Fish occurring on the Coast of Ireland." The Annals and magazine of natural history; zoology, botany, and geology 6, 402-408. https://doi.org/10.1080/03745484109442640.

View This Item Online: https://www.biodiversitylibrary.org/item/19590

DOI: https://doi.org/10.1080/03745484109442640

Permalink: https://www.biodiversitylibrary.org/partpdf/36781

\section{Holding Institution}

Natural History Museum Library, London

\section{Sponsored by}

Natural History Museum Library, London

\section{Copyright \& Reuse}

Copyright Status: Public domain. The BHL considers that this work is no longer under copyright protection.

This document was created from content at the Biodiversity Heritage Library, the world's largest open access digital library for biodiversity literature and archives. Visit BHL at https://www.biodiversitylibrary.org. 